\title{
Uji Daya Hambat dan Toksisitas Ekstrak Daun Jamblang [Syzygium cumini (L.) Skeels] Terhadap Pertumbuhan Bakteri Staphylococcus epidermidis \\ (Test The Tasteability and Toxicity of Jamblang [Syzygium cumini ( L.) Skeels] Leaf Extract Against Staphylococcus epidermidis Bacteria Growth )
}

\author{
Nurmeily Rachmawati ${ }^{1 *}$, Gina Maulidiyah $^{2}, \&$ Aminah $^{3}$ \\ 1,2,3 Jurusan Teknologi Laboratorium Medis, Politeknik Kesehatan Banten, Indonesia \\ Jl. Dr. Sitanala, Tangerang, 15121, Indonesia \\ Email : nurmeily.rachmawati@gmail.com
}

Memasukkan: Desember 2020, Diterima: Februari 2021.

\begin{abstract}
Jamblang is a tropical plant that is widely grown in Indonesia. According to preclinical studies, jamblang plants have benefits as an antioxidants, anti-inflammatory, anti-cancer, and antibacterial. The content of active compounds in jamblang leaves can act as an antibacterial agent against Staphylococcus auereus and Streptococcus mutans in others research. The purpose of this study is to identify the antibacterial activity and toxicity of the jamblang leaves extract against Staphylococcus epidermidis bacteria. The method used in this experiment is Minimum Inhibitory Concentration (MIC) method using disc diffusion and Brine Shrimp Lethality Test (BSLT) for toxicity testing. The research used ethanol extract of jamblang leaves [Syzygium cumini (L.) Skeels] with various concentrations $(20 \%, 40 \%, 60 \%$ and $80 \%)$, the test bacteria used was pure cultures of Staphylococcus epidermidis, and $30 \mu \mathrm{g}$ of chloramphenicol as the positive control, $10 \%$ DMSO solution as the negative control. A phytochemical test was conducted to determine the content of active compounds in jamblang leaves extract. The results showed that the ethanol extract of jamblang leaves contained flavonoids, tannins, saponins, and steroids with a total flavonoid content was $1.38 \%$. The toxicity test using BSLT method was resulted $\mathrm{LC}_{50}$ value is $485.50 \mathrm{ppm}$ which indicated that the plant extract is toxic, and if value of $\mathrm{LC}_{50}$ was below $1000 \mathrm{ppm}$ its indicate as toxic properties. The result of MIC value was obtained with a level of concentration at $20 \%$ and a $9 \mathrm{~mm}$ diameter inhibition zone therefore was categorized as moderate antibacterial based on Clinical and Laboratory Standard Institute (CSLI).
\end{abstract}

Keywords: Leaves extracts of Jamblang, Minimum Inhibitory Concencentration, Staphylococcus epidermidis, toxicity

\begin{abstract}
ABSTRAK
Jamblang merupakan salah satu tanaman tropis yang banyak tumbuh di Indonesia. Menurut studi praklinis yang dilakukan tanaman jamblang memiliki aktivitas sebagai antioksidan, antiinflamasi, antikanker, dan antibakteri. Kandungan senyawa aktif dalam daun jamblang mampu berperan sebagai zat antibakteri terhadap Staphylococcus auereus dan Streptococcus mutans pada penelitian lain. Tujuan penelitian ini untuk mengetahui aktivitas antibakteri dan toksisitas dari ekstrak daun jamblang terhadap bakteri Staphylococcus epidermidis. Metode yang digunakan pada penelitian ini adalah metode Konsentrasi Hambat Minimum (KHM) dengan cara difusi cakram dan Brine Shrimp Lethality Test (BSLT ) untuk uji toksisitasnya. Penelitian ini menggunakan ekstrak etanol daun jamblang [Syzygium cumini (L.) Skeels] dengan variasi konsentrasi 20\%, 40\%, 60\% dan $80 \%$, bakteri uji yang digunakan adalah biakan murni Staphylococcus epidermidis, dan menggunakan kontrol positif $30 \mu \mathrm{g}$ kloramfenikol, kontrol negatif DMSO 10\%. Uji fitokimia dilakukan untuk mengetahui kandungan senyawa aktif pada ekstrak daun jamblang. Hasilnya menunjukkan ekstrak etanol daun jamblang mengandung zat flavonoid, tannin, saponin, dan steroid dengan total kadar flavonoid $1,38 \%$. Untuk uji toksisitas menggunakan metode BSLT menghasilkan nilai $\mathrm{LC}_{50}$ yaitu 485,50 ppm yang menunjukkan ekstrak tanaman bersifat toksik dan jika nilai $\mathrm{LC}_{50}$ dibawah 1000 ppm maka ekstrak tersebut bersifat toksik. Hasil nilai KHM diperoleh pada konsentrasi 20\% dengan diameter zona hambat $9 \mathrm{~mm}$ dan dikategorikan sebagai antibakteri sedang menurut institute standar laboratorium dan klinik (CSLI).
\end{abstract}

Kata Kunci: Ekstrak daun jamblang, Konsentrasi hambat minimum, Staphylococcus epidermidis, toksisitas 


\section{PENDAHULUAN}

Salah satu tanaman yang dapat digunakan sebagai obat herbal adalah tanaman jamblang. Tanaman ini banyak digunakan untuk kesehatan terutama pengobatan tradisional oleh masyarakat Indonesia. Tanaman jamblang [Syzygium cumini (L.) Skeels] merupakan pohon tropis hijau dan sangat banyak tumbuh di Pakistan, India, Bangladesh, dan Indonesia. Semua bagian tanaman ini dapat digunakan untuk tujuan pengobatan. Studi praklinis menunjukkan bahwa batang, daun, dan buah dari tanaman jamblang memiliki aktivitas sebagai antioksidan, anti inflamasi, obat cacing, antikanker, antibakteri, dan anti diabetes (Haroon 2015).

Serbuk daun jamblang digunakan dalam pengobatan tradisional di India untuk memperkuat bagian gigi dan gusi, sedangkan bijinya dapat digunakan sebagai pengobatan untuk antidibates (Kumar et al. 2009). Daun jamblang mengandung banyak flavonoid, terutama glikosida flavonoid. Daun jamblang juga mengandung banyak tannin, alkaloid, saponin, dan terpenoid (Dewi dkk. 2018). Kandungan fitokimia daun jamblang juga dipengaruhi oleh teknik dan pemilihan jenis pelarut. Hal ini sejalan dengan penelitian yang dilakukan oleh Putri (2014) yang menyatakan metode ekstraksi yang berbeda akan menghasilkan rendeman dan kandungan zat fitokimia pada ekstrak bawang rambut yang berbeda. Oleh sebab itu perlu dilakukan lpenelitian lebih lanjut terkait kandungan fitokimia ekstrak daun jamblang.

Flavonoid, tannin, dan terpenoid dari daun jamblang dapat mengganggu permeabilitas membran sel bakteri, sehingga pertumbuhan bakteri terganggu. Alkaloid mengganggu dinding sel bakteri dan menyisipkan ke dinding sel atau DNA yang bisa menyebabkan kematian sel bakteri (Sungkar dkk. 2018). Senyawa polifenol dalam ekstrak etanol daun jamblang dapat menghambat jumlah Streptococcus mutans yang melekat pada hidroksiapatit termasuk senyawa polifenol dengan berat molekul tinggi, yaitu tanin. Kandungan zat fitokimia inilah yang menyebabkan ekstrak daun jamblang dapat berperan sebagai antioksidan maupun sebagai antibakteri. Kajian daya anti Staphylococcus aureus telah dilakukan pada fermentasi beberapa tumbuhan obat (Kasim dkk 2005) dan pada penelitian (Hosmat et al. 2013) melaporkan zona hambatan dalam ekstrak etanol daun Syzygium cumini L. $(11 \mathrm{~mm})$ terhadap Staphylococcus aureus yang juga sesuai temuan (Imran et al. 2017) (8-20 mm) terhadap Methicilin Resistant Staphylococcus aureus (MRSA) dan Methicillinsusceptible Staphylococcus aureus (MSSA). Sedangkan Mustopa dkk. (2018) melakukan kajian beberapa factor yang mempengaruhi anti bakteri Staphylococcus aureus.

Pemilihan daun jamblang sebagai bahan tanaman pada penelitian ini didasarkan pada kandungan dan penggunaannya secara empirik. Daun jamblang mengalami proses regenerasi lebih cepat dibandingkan lainnya, sehingga pengambilan dalam jumlah banyak tidak menyebabkan kepunahan spesies tanaman ini. Selain itu, daun jamblang juga dapat dimanfaatkan lebih cepat karena tidak menunggu musim (Septiani 2018).

Uji aktivitas bakteri dilakukan terhadap Staphylococcus epidermidis dan uji toksisitas dilakukan dengan metode Brine Shrimp Lethality Test (BSLT). Bakteri Staphylococcus epidermidis merupakan bakteri flora normal pada kulit dan komensal mukosa yang hidup pada kulit manusia. Bakteri ini dapat menyebabkan infeksi pada pasien dengan gangguan kekebalan dan sering menjadi penyebab penyakit nosokomial (Otto 2012). Sedangkan metode uji toksisitas menggunakan larva (nauplia) Artemia salina Leach yang digunakan sebagai hewan coba. Jumlah kematian larva dihitung setelah 24 jam perlakuan dan hasilnya dinilai sebagai nilai $\mathrm{LC}_{50}$ atau $\mathrm{LD}_{50}$, dosis yang dibutuhkan untuk membunuh $50 \%$ larva (Thomas 2007). Metode ini merupakan salah satu metode untuk menguji bahan-bahan yang bersifat toksik dan digunakan sebagai suatu bioassay yang pertama untuk penelitian bahan alam dan sebagai agen antitumor, pestisida, dan skrining ekstrak tumbuhan untuk aktivitas farmakologi (Kuete 2013). Potensi ekstrak jamblang ini dapat ditinjau terhadap potensi antibakterinya pada Staphyloccocus epidermidis untuk melihat apakah ekstrak ini mampu menghambat pertumbuhan dari bakteri tersebut. Selain itu ekstrak jamblang ini juga dapat dikaji terkait toksisitasnya sehingga harapan dari riset ini 
dapat dikembangkan menjadi suatu produk untuk penggunaan secara topical dengan melihat hasil dari uji aktivitas antibakteri dan toksisitasnya.

\section{BAHAN DAN METODE KERJA}

Sebanyak $2 \mathrm{~kg}$ daun jamblang segar dibersihkan dari kotoran dengan dicuci menggunakan air mengalir hingga bersih. Daun jamblang dipotong menjadi lebih kecil kemudian dikeringkan diudara terbuka. Sebanyak 500 gram simplisia daun jamblang yang telah kering kemudian dimaserasi dengan etanol dengan perbandingan 1:5 selama 24 jam. Proses ini bertujuan untuk memperoleh ekstrak daun jamblang. Selanjutnya dilakukan proses penyaringan kemudian dilakukan proses evaporasi untuk menguapkan pelarut pada suhu $40^{\circ} \mathrm{C}$. Ekstrak yang diperoleh disimpan dalam botol kaca gelap agar tidak terjadi kerusakan pada zat fitokimianya.

Uji fitokimia dilakukan secara kualitatif dan kuantitatif. Untuk uji alkaloid, fenolik, triterpenoid, hidrokuinon dilakukan secara kualitatif dari perubahan warna. Uji ini dilakukan mengikuti standar prosedur dari Laboratorium Biofarmaka, IPB, Bogor. Untuk uji alkaloid sebanyak 1 gram ekstrak ditambah dengan $5 \mathrm{~mL}$ klorofom lalu disaring daan filtrat ditambah dengan asam sulfat 2M. Lapisan asam dibagi menjadi 3 bagian untuk diuji dengan pereaksi dragendrof, mayer, dan wagner. Untuk uji fenolik diperlukan 5 gram ekstrak kemudian ditambahkan dengan akuades, lalu dipanaskan 5 menit kemudian disaring dan filtratnya dilakukan uji flavonoid, tanin, dan saponin. Untuk uji triterpenoid diperlukan 1 gram ekstrak kemudian ditambahkan etanol panas lalu disaring dan filtratnya dipanaskan hingga kering, selanjutnya ditambahkan $1 \mathrm{~mL}$ dietil eter kemudian dihomogenkan lalu ditambahkan 1 tetes asam sulfat pekat dan asam asetat anhidrat. Untuk uji hidrokuinon diperlukan 1 gram ekstrak kemudian ditambahkan metanol lalu dipanaskan dan disaring, filtratnya ditambahkan $\mathrm{NaOH} 10 \%$ sebanyak 3 tetes.

Uji fitokimia secara kuantitatif dilakukan dengan mengukur kadar total flavonoid menggunakan metode spektrofotometri pada panjang gelombang $425 \mathrm{~nm}$. Pengukuran kadar total flavonoid dilakukan dengan membuat larutan induk yaitu $200 \mathrm{mg}$ ekstrak ditambah 1
$\mathrm{mL}$ larutan heksametilentetramin (HMT) 0,5\%, $20 \mathrm{~mL}$ aseton, $2 \mathrm{~mL}$ asam klorida, kemudian dihidrolisis dengan refluks selama 30 menit. Residu direfluks kembali dengan $20 \mathrm{~mL}$ aseton selama 30 menit dan filtrat diencerkan dalam labu ukur $100 \mathrm{ml}$ dengan aseton. $20 \mathrm{~mL}$ filtrat ditambah $20 \mathrm{~mL}$ air kemudian diekstrak sebanyak $3 \mathrm{x}$ dengan $15 \mathrm{~mL}$ etil asetat. Fraksi etil asetat dikumpulkan dan ditambah dengan etil asetat sampai $50 \mathrm{~mL}$ batas labu ukur. Prosedur ini mengacu pada standar operasional prosedur dari Laboratorium Biofarmaka, IPB Bogor.

Uji toksisitas dilakukan dengan mempersiapkan larva udang sebanyak $10 \mathrm{mg}$ telur udang dimasukkan kedalam $250 \mathrm{ml}$ air laut. Kemudian didiamkan selama $2 \times 24$ jam hingga menetas menjadi larva udang. Selanjutnya masing-masing vial yang terdapat 10 larva udang ditambahkan larutan uji ekstrak dengan konsentrasi $(1000,500$, $100,10) \mathrm{ppm}$. Selanjutnya didiamkan selama 24 jam untuk dihitung jumlah mortalitas dari larva udang tersebut. Untuk memperoleh nilai $\mathrm{LC}_{50}$ maka dilakukan perhitungan statistika dengan analisa probit.

Uji antimikroba ekstrak daun jamblang terhadap Staphylococcus epidermis dilakukan dengan metode disc diffusion. Bakteri uji merupakan kultur murni Staphyloccocus epidermidis ATCC 12228 yang diperoleh dari Laboratorium Universitas Indonesia. Ekstrak dilarutkan dengan $10 \%$ dimetilsulfoksida (DMSO) pada konsentrasi $20 \%, 40 \%, 60 \%, 80 \%$. Blank discs ekstrak diletakkan diatas media Mueller Hinton Agar, kemudian diinkubasi selama 24 jam pada suhu $37^{\circ} \mathrm{C}$. Zona hambat yang terbentuk diamati dan diukur diameternya menggunakan penggaris.

Data yang diperoleh kemudian disajikan dalam bentuk tabel dan gambar. Hasil penelitian yang diperoleh berupa rendeman ekstrak daun jamblang, uji fitokimia secara kualitatif dan kuantitatif untuk total flavonoid, uji toksisitas, dan aktivitas antibakteri terhadap Staphylococcus epidermidis.

\section{HASIL}

Penelitian dilakukan dengan membuat ekstrak daun jamblang dengan mengeringkan daun jamblang sebanyak $2 \mathrm{~kg}$. Simplisia daun 
jamblang yang didapat yaitu $500 \mathrm{~g}$ yang kemudian dilakukan maserasi dengan etanol $70 \%$ dengan perbandingan volume 1:5. Hasil maserasi dilakukan penguapan pelarut menggunakan rotary evaporator sehingga diperoleh rendeman ekstrak sebesar 18,65 gram (3,73\%). Rendeman ekstraksi dihitung berdasarkan rumus sebagai berikut (Dewatisari 2017).

$\%$ Rendemen $=($ Jumlah berat ekstrak berupa pasta (g) x $100 \%$ ) / Jumlah berat kering (g)

Ekstrak yang telah didapatkan kemudian dilakukan uji kualitatif fitokimia dan kuantitatif total flavonoid menggunakan spektrofotometer . Untuk mengetahui kandungan zat fitokimia pada ekstrak dapat dilakukan dengan uji perubahan warna untuk masing-masing parameter. Berdasarkan hasil pada Tabel 1 diperoleh bahwa ekstrak daun jamblang mengandung zat fitokimia yaitu flavonoid, tannin, saponin, dan steroid. Untuk uji postif flavonoid ditunjukkan dengan warna jingga, untuk uji positif tannin ditunjukkan dengan warna hitam kehijauan, sedangkan uji positif saponin dan steroid ditunjukkan dengan positif berbuih dan hijau kebiruan. Metode uji kualitatif fitokimia ini merupakan metode analisis berdasarkan Harborne (2017). Selanjutnya dilakukan uji kuantitatif untuk total flavonoid pada ekstrak. Untuk mengetahui kadar suatu zat dalam sampel dapat menggunakan metode spektrofotometri. Pada metode ini sinar yang melewati sampel akan mengalami interaksi sehingga dapat terjadi proses eksitasi maupun

Tabel 1. Hasil Uji Fitokimia Ekstrak Daun Jamblang

\begin{tabular}{ll}
\hline Parameter & Hasil \\
\hline Flavonoid & + \\
Alkaloid & - \\
Tanin & + \\
Saponin & + \\
Quinon & - \\
Steroid & + \\
Triterpenoid & - \\
\hline Total Flavonoid & $1,38 \%$ \\
\hline
\end{tabular}

Keterangan : $(+)=$ Terdeteksi, $(-)=$ Tidak terdeteksi absorbansi yang kemudian diteruskan ke detektor sehingga sinyal absorbansi yang terbaca dapat dikorelasikan dengan kadar zat tersebut (Mulja 1995).

Selanjutnya ekstrak yang diperoleh juga dilakukan uji toksisitas dengan metode BSLT dimana rerata mortalitas larva diolah secara statistika dengan analisis probit sehingga diperoleh nilai $\mathrm{LC}_{50}$. Untuk mendapatkan nilai $\mathrm{LC}_{50}$ ini dengan menghubungkan nilai logaritma dari persentase mortalitas hewan uji coba untuk diinterpolasi dalam persamaan $\mathrm{y}=\mathrm{a}+\mathrm{bx}$. Dimana nilai $\mathrm{y}, \mathrm{a}, \mathrm{b}$, dan $\mathrm{x}$ merupakan probit kematian hewan uji coba, konsentrasi regresi, slope, dan logaritma konsentrasi uji (Hendri dkk. 2010). Berikut adalah hasil uji toksisitas pada Tabel 2 sebagai berikut.

Selanjutnya ekstrak daun jamblang dilakukan uji aktivitas antibakteri terhadap bakteri Staphylococcus epidermidis dengan kontrol negatif adalah DMSO 10\% serta kontrol positif antibiotik kloramfenikol dengan metode paper disc. Berikut adalah hasil uji daya hambat ekstrak daun jamblang pada Tabel 3 dengan pengulangan sebanyak 6 kali.

\section{PEMBAHASAN}

Penelitian ini dilakukan untuk mengetahui kemampuan ekstrak daun jamblang dalam menghambat pertumbuhan bakteri Staphylococcus epidermidis serta uji toksisitas dari ekstrak daun jamblang tersebut. Pada penelitian ini menggunakan metode difusi cakram untuk uji aktivitas antibakteri. Hal ini dikarenakan metode difusi adalah metode yang sederhana, mudah prosedurnya dan dapat akurat hasilnya (Alimsardjono 2015). Metode ekstraksi yang digunakan pada penelitian ini adalah metode

Tabel 2. Hasil Uji Toksisitas Ekstrak Daun Jamblang

\begin{tabular}{lll}
\hline $\begin{array}{l}\text { Konsentrasi } \\
(\boldsymbol{\mu g} / \mathbf{m L})\end{array}$ & $\begin{array}{l}\text { \%Rerata Mortilitas } \\
\text { Larva Artemia } \\
\text { salina Leach }\end{array}$ & $\begin{array}{l}\mathbf{L C}_{\mathbf{5 0}} \\
(\boldsymbol{\mu g} / \mathbf{m L})\end{array}$ \\
\hline 1000 & $80 \%$ & \\
500 & $50 \%$ & 485.50 \\
100 & $40 \%$ & \\
10 & $20 \%$ & \\
\hline
\end{tabular}




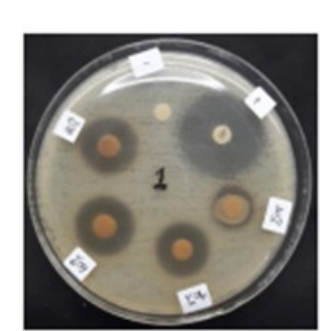

Pengulangan 1 : Uji Penelitian

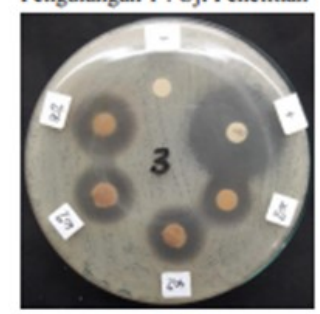

Pengulangan 3 : Uji Penelitian

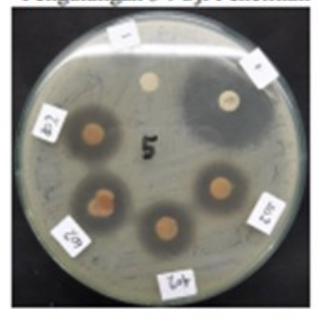

Pengulangan 4 : Uji Penelitian

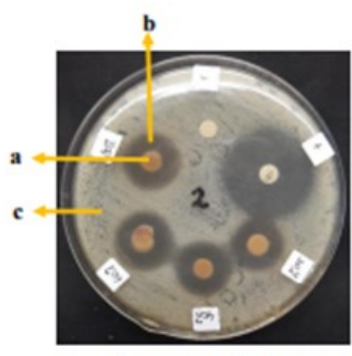

Pengulangan 2 : Uji Penelitian

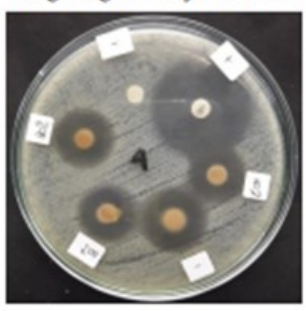

Pengulangan 4 : Uji Penelitian

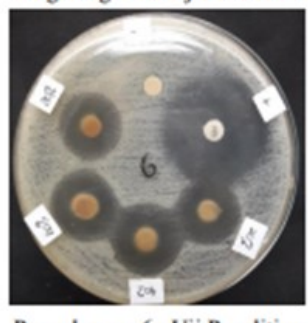

Pengulangan 6 : Uji Penelitian
Gambar 1. Aktivitas Antibakteri Ekstrak Daun Jamblang terhadap Staphylococcus epidermidis.

maserasi yaitu proses pengekstrakan simplisia menggunakan pelarut dengan beberapa kali pengocokan atau pengadukan pada temperatur ruang (Fatimah dkk. 2016). Uji toksisitas dengan metode BSLT menggunakan larva udang merupakan metode pendahuluan yang telah terbukti memiliki korelasi dengan daya toksisitas. Larva udang sebagai bioindikator sangat peka terhadap bahan toksik, sehingga toksisitas suatu bahan terhadap larva udang dapat dijadikan indikasi awal dari efek farmakologis bahan tersebut. Keunggulan metode ini ialah larva udang peka terhadap bahan uji, mudah dibiakkan, memiliki siklus hidup yang cepat, waktu uji cepat, mudah dilakukan, dan biaya relatif murah.

Hasil uji toksisitas memberikan nilai $\mathrm{LC}_{50}$ sebesar 485,50 ppm. Tolak ukur atau parameter yang digunakan untuk menunjukkan adanya aktivitas biologi suatu senyawa pada Artemia salina Leach yaitu dengan menghitung jumlah kematian larva udang akibat pemberian senyawa dengan konsentrasi yang telah ditetapkan. Hasil uji dikatakan efektif terhadap larva Artemia salina Leach apabila ekstrak yang diujikan menyebabkan $50 \%$ kematian pada kurang dari 1000 ppm. Dari hasil nilai $\mathrm{LC}_{50}$ yang diperoleh dapat dikatakan bahwa ekstrak daun jamblang ini bersifat toksik disebabkan nilai $\mathrm{LC}_{50}<1000$ ppm dan ekstrak tanaman dapat dikatakan toksik nila memiliki nilai $\mathrm{LC}_{50}$ dibawah 1000 ppm.

Selanjutnya hasil pemberian berbagai konsentrasi ekstrak daun jamblang dengan konsentrasi $20 \%, 40 \%, 60 \%$, dan $80 \%$ terhadap diameter zona hambat pertumbuhan bakteri Staphylococcus epidermidis menunjukkan adanya pengaruh dari setiap perlakuan yang berbeda-beda terhadap diameter zona hambat yang dihasilkan. Hal ini diketahui dengan terbentuknya daerah bening di sekitar cakram disk. Daerah bening yang terbentuk disebabkan oleh adanya pengaruh pemberian ekstrak daun jamblang. Hal ini berarti ekstrak daun jamblang mampu menyebabkan terjadinya hambatan pertumbuhan bakteri Staphylococcus epidermidis. Hal ini sesuai dengan Pelczar \& Chan (2008)

Tabel 3. Diameter Zona Hambat Ekstrak Daun Jamblang

\begin{tabular}{lllllll}
\hline Ulangan & \multicolumn{7}{l}{ Diameter Zona Hambat $(\mathbf{m m})$} & \multicolumn{3}{l}{ Kontrol $(\mathbf{m m})$} \\
\hline & $20 \%$ & $40 \%$ & $60 \%$ & $80 \%$ & $30 \mu \mathrm{g}$ Kloramfenikol & $\begin{array}{l}\text { DMSO } 10 \% \\
(-)\end{array}$ \\
1 & 12 & 18 & 20 & 20 & 30 & 0 \\
2 & 15 & 16 & 17 & 18 & 30 & 0 \\
3 & 13 & 14 & 16 & 20 & 30 & 0 \\
4 & 18 & 19 & 19 & 20 & 30 & 0 \\
5 & 14 & 15 & 16 & 16 & 30 & 0 \\
6 & 18 & 20 & 20 & 20 & 33 & 0 \\
Rata-rata & 15 & 17 & 18 & 19 & 31 & 0 \\
\hline
\end{tabular}


bahwa bahan antimikroba biasanya dapat diartikan sebagai bahan yang dapat mengganggu pertumbuhan dan metabolisme bakteri. Selain itu pada penelitian ini juga menggunakan perlakuan DMSO $10 \%$ sebagai kontrol negatif dan kloramfenikol sebagai kontrol positif. Pelarut DMSO merupakan pelarut organik yang dapat melarutkan zat organik dalam hal ini zat fitokimia dalam ekstrak daun jamblang. Pelarut ini berperan sebagai kontrol negatif karena digunakan sebagai pengencer untuk pembuatan konsnetrasi ekstrak yang diujikan terhadap bakteri Staphyloccocus epidermidis. Pemilihan pelarut ini agar mengurangi nilai positif palsu dari reaksi uji daya hambat yang terlihat pada DMSO $10 \%$ tidak ditemukanya diameter zona hambat. DMSO dapat digunakan sebagai pengencer ekstrak untuk memperoleh ekstrak dengan kadar konsentrasi tertentu (Assidqi dkk. 2012). Kontrol positif menggunakan antibiotik kloramfenikol dikarenakan kloramfenikol termasuk antibiotik spektrum luas. Interpretasi hasil berdasarkan pada terbentuknya zona hambat di sekitar disk pada pertumbuhan Staphylococcus epidermidis dan dibandingan dengan standar sensitivias menurut CLSI tahun 2017, digolongkan menjadi sensitif, intermediat, atau resisten. Berdasarkan CLSI 2017, untuk bakteri Staphylococcus spp. dengan menggunakan antibiotik kloramfenikol. Menurut Davis dan Stout daya hambat ekstrak terdiri dari beberapa katagori yaitu daya hambat ekstrak, dengan diameter zona hambat $\leq 5 \mathrm{~mm}$ dikategorikan lemah, zona hambat 5-10 mm dikategorikan sedang, zona hambat $10-20 \mathrm{~mm}$ dikategorikan kuat, zona hambat $\geq 20$ dikategorikan sangat kuat.

Hal ini sesuai dengan karakteristik bakteri Staphylococcus epidermidis. Kumar et al. (2009) yang menjelaskan bahwa flavonoid memiliki aktivitas antibakteri dengan mekanisme yang beragam, salah satunya membentuk kompleks dengan protein melalui ikatan hidrogen, efek hidrofobik, dan ikatan kovalen sehingga dapat menginaktivasi adhesin, enzim, serta pembentukan misel dari mikroba. Flavonoid yang bersifat lipofilik juga berperan dalam menganggu membran sel mikroba (Kumar et al. 2009 ). Senyawa flavonoid merupakan salah satu senyawa kimia yang terkandung dalam daun jamblang yang bersifat bakteriostatik (Jawetz et al. 2008). Mekanisme kerjanya dengan mendenaturasi protein sel bakteri dan merusak membran sitoplasma. Senyawa flavonoid dapat merusak membran sitoplasma yang dapat menyebabkan bocornya metabolit penting dan menginaktifkan sistem enzim bakteri. Kerusakan ini memungkinkan nukleotida dan asam amino merembes keluar dan mencegah masuknya bahanbahan aktif ke dalam sel, keadaan ini dapat menyebabkan kematian bakteri (Retnowati dkk. 2011). Mekanisme alkaloid sebagai antibakteri berhubungan dengan cara senyawa alkaloid dalam mengganggu komponen penyusun peptidoglikan pada sel bakteri sehingga pembentukkan sel tidak sempurna. Keadaan ini menyebabkan sel bakteri mudah mengalami lisis, baik berupa fisik maupun osmotik dan menyebabkan kematian sel. Diduga kerja alkaloid terlebih dahulu merusak dinding sel dan dilanjutkan kerja flavonoid yang merusak membran sitoplasma bakteri (Retnowati dkk. 2011).

Dari hasil penelitian yang diperoleh, diketahui bahwa semakin besar konsentrasi ekstrak yang digunakan, maka akan semakin besar pula diameter zona hambatnya. Penelitian ini menunjukkan bahwa konsentrasi terendah ekstrak daun jamblang yang dapat menghambat pertumbuhan bakteri Staphylococcus epidermidis berada pada konsentrasi $20 \%$.

\section{KESIMPULAN}

Penelitian ini memperoleh rendeman ekstrak etanol daun jamblang sebesar 18,65 gram $(3,73 \%)$ dengan nilai $\mathrm{LC}_{50}$ yaitu 4850,50 ppm yang menunjukkan ekstrak bersifat toksik. Uji fitokimia memberikan hasil bahwa ekstrak etanol daun jamblang mengandung senyawa aktif flavonoid, tannin, saponin, dan steroid yang ditunjukkan dari perubahan warna yang spesifik. Untuk mengetahui kadar total flavonoid dalam ekstrak menggunakan metode spektrofotometri dimana nilai absorbansi linear dengan konsentrasi zat dalam sampel yaitu sebesar $1,38 \%$. Nilai ini diperoleh dari hasil perhitungan absorbansi sampel, absorbansi blanko, dan absorbansi larutan standar. Hasil uji aktivitas antibakteri memberikan hasil bahwa ekstrak etanol daun jamblang mampu menghambat pertumbuhan Staphylococcus epidermidis yang ditunjukkan dari 
diameter zona hambat diberbagai konsentrasi ekstrak yang digunakan dalam penelitian.

\section{DAFTAR PUSTAKA}

Alimsardjono, L., PB. Purwono, PD. Endraswari, D. Kusumaningrum, \& NM. Mertaniasih. 2015. Buku Ajar Pemeriksaan Mikrobiologi pada Penyakit Infeksi. Jakarta: CV Sagung Seto.

Assidqi, K., W. Tjahjaningsih, \& S. Sigit. 2012. Potensi ekstrak daun petikan kebo (Euphorbia hirta) sebagai antibakteri terhadap Aeromonas hydrophila secara in vitro. Journal of Marine and Coastal Science. 1(2): 113-124.

Carballo, JL., ZL. Hernandez-Inda, P. Perez, \& MD. Garcia-Gravalos. 2002. A comparison between two brine shrimp assaysa to detect in vitro cytotoxicity in marine natural products. BMC Biotechnology 2 (17). https://doi.org/ 10.1186/1472-6750-2-17.

Dewatisari, WF., L. Rumiyanti, I. Rakhmawati. 2017. Rendeman dan skrining fitokimia pada ekstrak daun Sanseviera sp. Jurnal Penelitian Pertanian Terapan. 17 (3):197-202

Dewi, STR., \& S. Wahyuni. 2018. Uji Efek Anti Inflamasi rebusan daun jamblang (Syzygium cumini) pada mencit (Mus musculus). Media Farmasi 14 (1): 53-58

Fatimah, S., F. Nadifah, \& I. Burhanudin. 2016. Uji daya hambat ekstrak etanol kubis (Brassica oleraceae var. capitata f. alba) terhadap bakteri Staphylococcus aureus Secara In Vitro. BIOGENESIS Jurnal Ilmiah Biologi. 4 (2): 102-106.

Harborne, JB. 1987. Metode fitokimia penuntun cara modern menganalisis tumbuhan. Bandung Institut Teknologi Bandung Press

Haroon, R., S. Jelani, \& FK. Arshad. 2015. Comperative analysis of antioxidant profils of bark, leaves and seeds of Syzygium cumini L. (Indian Blackberry). International Journal of ReasearchGranthaalayah. 3 (5):13-26.

Hendri, M., G. Diansyah, \& J. Tampubolon. 2010. Konsentrasi letal (LC50-48 jam) logam tembaga $(\mathrm{Cu})$ dan logam kadmium $(\mathrm{Cd})$ terhadap tingkat mortalitas juwana kuda laut (Hippocampus spp). Jurnal Penelitian Sains. 13 (1): 26-30.
Hosmat. PD, KD. Sonawane, \& SR. Waghmere. 2013. Antibacterial activity of Vulgarol A extracted from leaves of Syzygium cumini L. leaves. Asian Journal Pharmatical Clinic Research. 6(4): 100-102.

Imran, M., M. Imran, \& S. Khan. 2017. Antibacterial activity of Syzygium cumini L. leaf extract against multidrug resistent patogenic bacteria. Journal of Applied Pharmaceutical Science. 7 (03): 168-174.

Jawetz, E., JL. Melnick, \& EA. Adelberg. 2008. Medical Microbiology. Jakarta: Salemba Medika.

Kasim, E. T. Yulinery, R. Hardiningsih, E. Triana, \& RNR. Napitupulu 2005. Daya anti Staphylococcus aureus dari fermentasi daun beberapa jenis tumbuhan obat. Jurnal Biologi Indonesia. 3(9): 397 - 404.

Kuete, V. 2013 Medical Plant Research in Africa: Pharmacology and Chemistry. USA:Elsivier

Kumar, A., R. Ilavarasan, T. Jayachandran, M. Decaraman, P. Aravindhan, N. Padmanabhan, \& MRV. Krishnan. 2009. Phytochemicals Investigation on a Tropical Plant, Syzygium cumini L. from Kattuppalayam, Erode District, Tamil Nadu, South India. Pakistan Journal of Nutrition 8 (1): 83-85.

Mulja, HM., \& Suharman. 1995. Analisis Instrumental. Surabaya: Airlangga University Press.

Mustopa, AZ., Hasim \& S. Amelia 2018. Pengaruh Suhu, pH, Enzim dan surfaktan terhadap plantarisin $\mathrm{F}$ rekombinan enkapsulasi sebagai anti bakteri Staphylococcus aureus dan Salmonella typhi. Jurnal Biologi Indonesia 14(1): 61 - 71.

Otto M. 2012. Molecular basis of Staphylococcus epidermidis infections. Semin Immunopathol. 34(2): 201-214.

Putri, DA. 2014. Pengaruh Metode Ekstraksi dan Konsentrasi terhadap Aktivitas Jahe Merah (Zingiber officinale var rubrum) Sebagai Antibakteri Escherchia coli. [Skripsi]. Bengkulu: Universitas Bengkulu. Hal: 14-32.

Retnowati, Y., N. Bialangi, \& NW. Posangi. 2011. Pertumbuhan bakteri Staphylococcus aureus pada media yang diekspos dengan infusa daun sambiloto. Saintek. 6(2): 1-9.

Septiani, R., Marianne, \& M. Nainggolan. 2018. Uji aktivitas antioksidan ekstrak etanol 
fraksi N-Heksan serta fraksi etil asetat daun jamblang (Syzygium cumini L. Skeels) dengan metode DPPH. Talenta 1 (2): 361-366.

Sungkar, S., D. Agustina, A. Supartinah, \& T. Haniastuti. 2018. The effect of jamblang (Syzygium cumini. (L) Skeels) leaves ethanolic extract on the adhesion of Streptococcus mutans to ydroxyapatite. Advances in Health research. 8: 294-297

Thomas, G. 2007. Medical Chemistry: An introduction 2nd ed. England : John Wiley and Sons Ltd. 